Scientia Militaria vol 44, no 1, 2016, pp 35-46. doi:10.5787/44-1- 1161

\title{
Go Spy Out the Land: Intelligence Preparations for World War I in South West Africa
}

\author{
James Stejskal •
}

\begin{abstract}
As World War I approached, the potential for conflict drove the principal future protagonists, England and Germany, to seek detailed information on their anticipated enemies, not just in Europe, but wherever their nations' interests crossed paths. After 1910, the Union of South Africa turned its eyes to the northwest to keep watch on its German neighbour in the colonial protectorate of Deutsch-Südwest-afrika. For South Africans of English descent, the question of Germany's intentions was especially important: the Kaiser's vow of support for the Afrikaners prior to the recently concluded Boer War of Independence (South African War) was still remembered with some trepidation, despite its bombastic nature. ${ }^{1}$ Despite this, neither side was prepared for war outside Europe. The study on which this article reports, investigated the role intelligence played in the African theatre of the conflict, specifically the South West African campaign, and how this affected the preparation, conduct, and final outcome of the war for both the Allies and the Germans. While few records of the missions undertaken or the intelligence produced survive to describe intelligence operations in detail, enough exists to paint a picture of the efforts undertaken during the war. The activities of English defence attachés, German Schutztruppe officers on leave, South African Scouts, as well as alleged spies were examined and we demonstrate here that military intelligence operations where successfully undertaken - provided policy makers and military leaders alike with the information necessary for the prosecution of the war.
\end{abstract}

Keywords: South Africa, Great War, German South West Africa, intelligence

\section{Introduction}

The serious study of intelligence operations in World War I is a subject that has, with a few exceptions, been largely neglected by historians. It has been ignored in large part because the campaign in Europe did not allow for its full utilisation, which in turn limited its effect on the war effort. Many factors contributed to this, including geographic constraints and operational difficulties, as well as the fact that many commanders did not wish for intelligence officers to intrude into their domain. As the battlefields of Europe were the focal point of the war, it is understandable that few authors have strayed far from this arena. Thus far, only works such as John Keegan's Intelligence in war have dealt with the subject, usually in episodic fashion. $^{2}$

James Stejskal holds a Master's Degree in Military Studies and a Bachelor's Degree in History and is author of a number of articles on military history and conflict archaeology. His first book, The Horns of the Beast; The Swakop River Campaign and World War I in South-West Africa, 1914-15, was published in 2014 by Helion \& Company, Solihull, West Midlands. 
World War I, as fought outside Europe, has been characterised as a so-called "side-show" by many historians. Nevertheless, it was an important aspect of the conflict. Its final resolution in 1918 would alter the maps of the Middle East and Africa and set the course for a turbulent $20^{\text {th }}$ century. $^{3}$

The campaign to conquer German South West Africa (GSWA) was one such case and military intelligence operations - where successfully undertaken - often provided military leaders with the information necessary for the prosecution of the war. The South African Union Defence Force (UDF) would undertake two campaigns in Africa at the behest of the United Kingdom, and in both it would rely mostly on its own capabilities to supply the information it needed to prosecute the war. ${ }^{4}$

\section{Setting the stage}

Prior to 1914, Britain's leadership decided that preservation of its command of the high seas was of paramount importance and would require the elimination of any challenge to the Royal Navy. ${ }^{5}$ For the Admiralty, the threat would come not only from Germany's fleet, but from its colonies as well. Germany controlled a number of ports in Africa and the Far East, which could conceivably provide safe havens or resupply for its merchant raiders. Additionally, wireless stations in German South West Africa, Togo, German East Africa and the Far East enabled the homeland to communicate easily with the Kriegsmarine and naval auxiliaries. ${ }^{6}$

For Germany, the campaigns in the colonial protectorates were mostly about survival. While preparations had been made for maritime commercial warfare against England, few measures were taken to protect its colonies. With limited manpower and resources, Germany's colonial administrators and Schutztruppe commanders were under no illusion that they had the capability to take offensive action against Britain. ${ }^{7}$ Their plans and actions centred on the premise that the outcome of any war and, hence, the fate of the colonies would be settled on the battlefields of Europe. ${ }^{8}$

The Union of South Africa would be drawn into the conflict by several factors. First it was required by its constitution to support the United Kingdom in the case of war. Second, Prime Minister General Louis Botha and Minister of Defence General Jan Smuts hoped that participation in the war would unify the Boer and British populations of the young country. Finally, there was an unspoken desire (at least publicly) to acquire the territory of South West Africa as a reward, should the Allies win. ${ }^{9}$

Expecting war would come, England and Germany used their available assets to determine the intentions and capabilities of their rivals. This was especially true in the overseas territories of both countries, not just in Europe. The British were keenly interested in Germany's colonial ambitions and intentions at the highest levels in Berlin. They also sought out the smallest details on the colonies themselves. This included information that would eventually form handbooks called Military Reports on many countries of interest.

Following its establishment as a self-governing dominion of the United Kingdom after the South African War (1899-1902), the Union of South Africa also began to keep watch on its neighbour to the northwest, GSWA. The question of GSWA was a divisive factor for South Africans. To some, Germany was a threat and its colony a potential acquisition for territorial aggrandisement. For many, especially the Afrikaners, the Germans were felt to be a better ally than the 'English' with whom they had only recently concluded a bloody war. ${ }^{10}$ 


\section{Prelude to war}

In the late $19^{\text {th }}$ century, Britain began to re-evaluate the threat posed by other powers in Europe. Germany would replace France and Russia as Britain's first concern due to Kaiser Wilhelm II's aggressive policies, including his acceptance of Admiral Tirpitz's plan for a high seas fleet, which caused anxiety in many foreign capitals. Without the genius of Bismarck, Germany lost a rational course of balanced power and provided Britain with a new enemy. While London contemplated future action, Berlin naively chose to believe the 1885 Treaty of Berlin would mean its colonies were safe from foreign aggression. Britain, however, would demonstrate that it had few reservations about extending the war beyond Europe; Germany's colonies were seen as a strategic threat to its Empire and commerce. ${ }^{11}$

In the early 1900s, Europe was inching towards war. Beyond the ivory towers and mirror-lined halls of power, the military leaders of Britain and Germany recognised that war was most likely inevitable, and they wanted to know their future opponents' intentions and capabilities. In the absence of a declared war, there were a number of methodologies used by both the Germans and the British to collect intelligence. Seemingly, however, the British were more accomplished at the task than their continental rivals. The Union of South Africa, only created in 1910, had little in the way of a functioning defence staff and no separate intelligence organisation in the run-up to the Great War. Much of what its army required to function would be cobbled together on an ad hoc basis once the leadership in Pretoria made a decision to go to war and the force would have to catch up when the time for battle came. ${ }^{12}$

Prior to World War I, military intelligence was still a primitive art form and those who practiced it were often unappreciated by the officers and men of the line. To many, the work was considered unsuitable

for professional officers, and those who were in that field were often thought to be incapable of commanding combat troops. To complicate matters further, intelligence work was generally done on an ad hoc basis; units were formed and officers assigned as the need arose and dispensed of when no longer needed. Although a formal military intelligence structure was created within the British Army in 1899, the field elements were disbanded in 1901, only to be recreated in $1912 .{ }^{13}$ Even then, only a few enlightened senior officers understood the immense value of military intelligence. Prior to World War I, South Africa's Union Defence Force had no organic intelligence service, which is surprising given the success of the ZuidAfrikaansche Republiek Geheime Dienst (South African Republic Secret Service). ${ }^{14}$ A comparable capability would perhaps have given the South African government better initial insight into Germany's capabilities in the territory. The UDF General Staff was tasked to collect intelligence at the beginning of the war and, although a number of scout units were available to the commander, there was little coordination of assets and operational capabilities. ${ }^{15}$ What South Africa did have were the UDF's scout units (also known as intelligence units), a direct legacy of units like Danie Theron's Verkenningskorps (Corps of Guides) that was so effectively employed in the South African War. ${ }^{16}$ Additionally, the South Africans would employ indigenous guides and scouts, as they had in previous conflicts, with mixed results in the upcoming war.

\section{The means of intelligence}

A differentiation needs to be made between two general forms of military intelligence: strategic and tactical. Strategic intelligence collection is geared towards obtaining information that permits one nation to understand the capabilities and intentions of another national state or entity. For a nation's military, this 
consists of the collection and assessment of information that will shed light on an opponent's grand strategy. This intelligence helps the commander devise a strategy to defeat the enemy. Tactical intelligence is simply the information required for planning and conducting tactical operations.

At the beginning of World War I, several methods of intelligence collection were practiced. The first and safest method of collection was the study of open-source materials, i.e. newspapers and magazines. ${ }^{17}$ Especially valuable were military journals or books written by an adversary nation's military officers, which described new tactics and trends.

Another useful method was the use of military attachés who were assigned to embassies in foreign capitals. They had the ability (some more competently than others) to elicit useful information from hostcountry officers through discussions or from direct observation of manoeuvres. ${ }^{18}$ With the exception of a short period during the Herero and Nama rebellions (1903-1907), the British had no military representation in GSWA (the contributions of the attachés that served during that period will be discussed later).

Diplomatic reporting about parliamentary debates, as well as that of business travellers was also an important source of information. John Cleverley, for example, who was the resident magistrate in the British territorial enclave of Walvis Bay, ran an extensive network of informants who operated in the western and central parts of the German colony, and his reports were relayed to the Ministry of Defence and the Colonial Office. $^{19}$

Cooperation between allied nations sometimes yielded good information, but the acquisition of such intelligence always had to be assessed to determine whether it was meant to influence as well as inform. Furthermore, understanding any faulty assumptions that might have been applied to their assessment was of equal importance.

The most difficult and dangerous method was espionage by men and women on the ground - what is now called 'human intelligence' or HUMINT. The risks entailed sometimes brought great reward, but failure could lead to a diplomatic incident or the death of an agent or asset.

Wireless intercepts as a nascent form of signals intelligence (SIGINT) also played a role in the GSWA campaign. Listening to the enemy's communications, especially when radio security was poor, provided the commanders with a wealth of information on enemy dispositions and intentions. During the campaign. This was especially true at the tactical level.

Once the battle had been joined, scouts and aerial observers (today called 'intelligence, surveillance, and reconnaissance forces') were responsible for the collection of tactical information on the battlefield for the military commander to plan his operations. A few examples from across the spectrum of intelligence collection will illustrate the methods used by the combatants.

\section{On their own - the colonial Germans}

The commander of the territorial protection forces in German South West Africa had no illusions as to his precarious position, despite Berlin's seeming naiveté. ${ }^{20}$ As early as 1908 , he was writing classified telegrams from Windhoek to the German legations and embassies in Cape Town, Luanda, Lisbon, and London, seeking information on the Portuguese troops in Angola and the British in the Cape Colony. He tasked the offices to provide him information on the order of battle (OB), including on types of formations, 
locations, and weapons, and the strength of units - with numbers of white and coloured troops. Additionally, the newest maps of Angola and the Cape Colony were requested with the promise of reimbursement. ${ }^{21}$

The responses received in Windhoek often left much to be desired, as the reply from German Consul General HP von Humboldt in Cape Town demonstrates. He declared it would be easier to ask the British in London for the information, as local inquiries might lead to mistrust. Clearly, Von Humboldt was not a man to undertake intelligence missions for the military. The German Consul in Boma, Congo who had responsibility for Portuguese Angola was more forthcoming and, in a cable response, detailed how he was able to obtain and send the latest maps and $\mathrm{OB}$ by courier to Windhoek. Eventually, a comprehensive outline of the military organisation of the South African military was delivered, but it would have been outdated by the time war began. ${ }^{22}$

Among the German missionaries working with the native peoples in South Africa, many retained strong ties to their homeland. Although most were suspected of spying for Berlin, many provided information on the situation in South Africa to their society offices in Germany. Prior to World War I, their reports usually concerned the mood of the indigenous people; information that was important to protectorate administrators concerned with cross-border influences on their 'own' native populations. Often, the true value of missionaries lay in countering misinformation and rumours. ${ }^{23}$

Prior to the war, several German officers travelled into the Cape Colony and reported their observations when they returned to their home base. One archived report submitted by Schutztruppe Senior Lieutenant (Sr Lt) Wittmann in 1909, included newspaper clippings concerning the Cape's military, as well as finely detailed sketches he made of defensive points on the Cape Peninsula and the Durban harbour batteries. It is difficult to determine how many such trips were undertaken, but the type of intelligence collected, especially on harbour defences, shows the Germans were clearly interested in their neighbour's military operations and capabilities. ${ }^{24}$

In 1914, despite not having a dedicated intelligence arm within the Schutztruppe, the Germans had a relatively clear understanding of their opponents' military structures, but little idea of their strategies other than in the most general terms. ${ }^{25}$ For that matter, the South Africans had no idea what their own strategy would be until war broke out. The Germans, limited by manpower and a lack of transport, were resigned to be isolated from their homeland and on the defensive. ${ }^{26}$

\section{Attachés and spies - Britain and the German threat}

Although Britain played an ancillary role in the campaign to capture GSWA, its intelligence operations prior to the war assisted the Union's effort in specific areas. In the late $19^{\text {th }}$ and early $20^{\text {th }}$ centuries, protection of her Imperial domain was of the utmost concern for Britain. Thus many politicians and military officers saw the German colonisation of Africa as a possible threat from its outset.

In most British colonies, colonial administrators, such as magistrates, were often drawn from a cadre of trained military police officers. This held true for the Cape Colony's magistrates in Bechuanaland and Walvis Bay whose job often focused on monitoring the indigenous peoples and their grievances as well as aspirations. Prior to World War I, the resident magistrates reported on native affairs in neighbouring GSWA and became familiar with the political and military situation in the German protectorate. Although colonial intelligence gathering had been given a home in the Home Section of the Secret Service Bureau created in 1909, the emphasis of that Bureau was on the threat of Bolshevism and anti-colonial movements in Britain's 
territories. ${ }^{27}$ Britain's concerns about her own colonies' indigenous populations were a major reason why she would not allow armed rebels to use Bechuanaland as a safe haven during the Herero and Nama uprisings in GSWA. ${ }^{28}$

Military attachés assigned overseas were important sources of strategic intelligence information before the war and did much to inform the thinking of the British Foreign and War Offices about German intentions as well as capabilities. British military attachés provided intelligence that was very much responsible for shaping perceptions towards Germany in the lead up to the war. ${ }^{29}$

Lieutenant Colonel Frederick Trench, DSO, was the British military attaché to the German headquarters in GSWA from 1905 to 1906 during the Herero and Nama uprisings and in Berlin thereafter. We know little of Trench except that he was an artillery officer and veteran of the South African War during which he earned the DSO. He later met Kaiser Wilhelm II, whom he apparently impressed with his German language ability and his suitability for life at court, what the Germans called Hoffähigkeit. The Kaiser requested Trench by name to serve as a military observer in GSWA where a ruthlessly effective commander, Lt Gen Adrian Dietrich Lothar von Trotha, was suppressing an internal rebellion. Trench's secret field reports were sent to his military superiors and to the governor of the Cape Colony who forwarded them to the Foreign Office in London and the British Embassy in Berlin. For a little over a year, Trench submitted his observations on Von Trotha, the insurgency, the Schutztruppe and German intentions towards the Cape Colony. A great deal of his reporting can be found in the British Army intelligence handbook Military report on German South-West Africa, that was first printed in 1906 and re-issued in 1913. From archival records, it is clear that much of the handbook was taken verbatim from Trench's reports and those of his successor, Major Wade.

Trench also submitted a number of maps that would have been valuable to a military planner, including details of the German communications network in the protectorate, showing rail, telegraph, and heliograph connections throughout the country. ${ }^{30}$

Notably, Trench pinpointed suitable targets for destruction in the event of war - the submarine telegraph cable, the wharves and piers at Swakopmund, and the water desalinisation condensers at Lüderitzbucht. With the exception of the condensers, all of these sites were disabled or attacked in August and September 1914. ${ }^{31}$

In a strategic context, Trench assessed the Germans were preparing for possible offensive action against the Cape Colony. This was a theme that Trench would continue, following his reassignment to Berlin in 1906 where he reported extensively on the bellicose nature of the Germans towards England. In one report, Trench states:

I cannot escape the impression that the suppression of the native revolt is going hand in hand with preparations for the subsequent use of the protectorate troops - or a portion of them - across the Orange River should the occasion demand it ... ${ }^{32}$

The archived copy of Trench's report is bound together with a number of translated and de-ciphered secret telegrams detailing logistics issues between the German headquarters in GSWA and the German consulate in Cape Town. Trench does not say where he obtained the telegrams, but he uses them well to illustrate his assessments. ${ }^{33}$ England's military attachés shaped strategic thinking prior to World War I, especially its perception of Germany as an aggressor, and it seems clear that Trench and Wade were influential in decisions by London and Pretoria about Germany and its colonies at the outset of the war. ${ }^{34}$ 
Few reliable accounts of espionage in GSWA exist and rarer still are any official records of intelligence reporting. One notable exception is Alexander Paterson Scotland who arrived in Cape Town from Scotland in 1902. Too late to take part in the South African War, he stayed in the colony and found work on the border between the Cape Colony and GSWA, where he became involved in the ongoing rebellion, primarily supplying the German forces. According to his biography, written after World War II, he learned to speak German and actually joined the Schutztruppe taking part in several operations around 1905-6. All the while, he was reporting on German activities to British agents. By the time World War I rolled around, Scotland fell afoul of German authorities and was detained in Windhoek until the South Africans captured the city in July 1915. After his release, he made his way to England where he continued his work in Europe as a British Army intelligence officer. ${ }^{35}$ While spy stories are often sensational, the actual contributions made are generally not so spectacular and rarely useful once the messy business of battlefield operations begins.

\section{Late to the game - the South Africans}

At the outset of the war, the Union Defence Force (UDF) was not organised to conduct intelligence operations against the Germans. The UDF's organisation for meeting its requirements was mostly ad hoc at the beginning, and was largely focused on tactical intelligence. The General Staff section of the UDF was tasked for the mission just prior to the hastily organised invasion of GSWA and efforts revolved around the deployment of scouts and the newly developed art of wireless interception.

The mission of Major Langbaard Grobler is a case in point. He and his 50-man unit, known as Grobler's Scouts, were deployed to Walvis Bay where he was instructed to collect information on the German town of Swakopmund and the surrounding area. ${ }^{36}$ Botha and the other Union commanders were very familiar with the employment of mounted reconnaissance scouts, having used them extensively against the British. Of scouts and their product (tactical intelligence) Sir Robert Baden-Powell said,

Either the winners have won through knowing all about the numbers and position of their adversaries ... or the loser, through ignorance of these points, has been unable to save himself. ${ }^{37}$

The Germans had great respect for the capabilities of the Boer commandos and their scouts, and their official history of the campaign refers to specific burgher officers known for their reconnaissance skills. The history makes it clear that the South Africans also used indigenous troops to scout out the land. On 22 February 1915, a Schutztruppe patrol encountered and routed a South African patrol near the village of Garub, near Aus, where the Germans were facing General Mackenzie's troops. The patrol comprised Nama scouts led by a white officer, and, in the skirmish, the officer and two Nama were killed. Upon investigation, the Germans found the dead white officer was Captain CK Meillon of the Imperial Light Horse, who had lived in Lüderitzbucht before the war, ostensibly as a photographer and diamond prospector. These activities would have provided him excellent access to the countryside and a way to collect information

unobtrusively. Because of this, the Germans were convinced that he must have been a spy. ${ }^{38}$ Whatever Meillon's pre-war affiliation actually was, at the outset of the war, the UDF saw his value and employed him for service in a position where his skills and area knowledge could be best used - as a reconnaissance scout leader.

In the northern campaign, Botha would employ six mounted scout elements known as intelligence units, each comprised about 50 men, to carry out forward area reconnaissance in force. ${ }^{39}$ Botha would also 
make use of signal intercept operations to collect information on an enemy that employed poor radio and telegraph communications security. The Germans had a habit of mixing encrypted traffic, usually code words or names, with 'clear' or unencrypted traffic, which facilitated the South African listener's chances of breaking the message. The Germans were somehow able to recover a South African radio intercept team's notebook from Swakopmund that contained detailed information about German operations, movements and strengths. Strangely, that did not deter the Germans from continuing their bad habits. ${ }^{40}$

Knowledge of the terrain is as important as knowing the enemy and although scouts can be of great utility in this regard, good maps are better still. A recent study suggested that the South Africans did not have access to good maps of the protectorate and the British produced the few that were available. ${ }^{41}$ In fact, the official South African history of the campaign mentions "Map S.1" used by General Botha to plan his advance up the Swakop River Valley. ${ }^{42}$ A surviving copy of this map was recently discovered and evaluated. According to the map's datum, it is clear that it was only one of a number of different maps produced by the UDF's General Staff Intelligence Topographic Section in $1915 .{ }^{43}$ Moreover, not only was the S.1 map based on German maps from 1910 (possibly obtained by South African traders or miners for the government), it was also very accurate and comparable to modern maps. In this regard, South African forces in GSWA had an advantage. They were aided by excellent maps (albeit in very limited numbers), local guides and mounted scouts, all of which contributed to the success of the campaign. Throughout the course of the campaign, the indigenous peoples of GSWA saw the South Africans as liberators - at least until after the war - and provided information and assistance to help rid their homeland of the German colonial oppressor. Contemporary German accounts and the official history repeatedly noted the problem of indigenous spies in their midst and attributed the failure of most booby-traps and mines to the compromise by locals who pointed them out to UDF troops as soon as the Germans departed from an area. ${ }^{44}$

With the advent of war, strategic intelligence became of secondary importance and tactical intelligence came to the fore. The side that possessed the best, most up-to-date information on his enemy and terrain would have an edge over his opponent. While the Germans had the 'home field' advantage, they would rapidly lose it to the South Africans who made better and more aggressive use of intelligence methodologies.

With the possible exception of the Battle of Sandfontein, the South Africans took every opportunity to employ intelligence assets and use the information gained from them to conduct operations. During the precipitous initial advance into GSWA in September 1914, General HT Lukin's "A” Force was ambushed by the German Schutztruppe at Sandfontein and overwhelmed. The Germans had deployed advance scouts and surveillance elements and were possibly aided by a South African traitor who revealed the South African attack plan. The Germans not only located, tracked and fixed the South Africans, but also repelled a UDF relief column, ensuring the failure of Lukin's invasion plan. This would be one of the last such intelligence successes the Germans would pull off during the campaign. It was also the most serious of the South African intelligence failures of the campaign. ${ }^{45}$

In December 1914, South African General Louis Botha landed his troops at Walvis Bay, beginning the second phase of operations in what would become the Swakop River Campaign in the northern part of the German protectorate. As he moved forward, first to Swakopmund and then inland, he deployed the UDF's intelligence units to reconnoitre the territory in advance of the front line while using signal units to monitor German wireless transmissions. The combination of both methods allowed Botha to determine the placement and strength of his opponent accurately while the Germans remained largely in the dark about what was to their front. ${ }^{46}$ 
As Botha began his move forward from the coast prior to the pivotal battles at Riet, Pforte, and Jakalswater that took place on 20 March 1914, he was able to estimate the enemy strength and disposition - including commanders' names - with some accuracy. A report by Major JGW Leipoldt, DSO, a surveyor and intelligence officer with Botha's general headquarters, shows the detail the South Africans had garnered from intercepts:

The Pforte position was known to be occupied by at least 2 mounted companies (German company 175 to 200 rifles) and a section of Field Artillery. The Riet position by at least four mounted companies and a battery of Field Artillery, while a general reserve of two batteries and four or five companies was at Jackalswater and Modderfontein. ${ }^{47}$

On 18 March 1915, Botha moved forward with approximately 7500 troops, outnumbering the Germans nearly tenfold. ${ }^{48}$ Despite knowing the enemy was ahead of them, the Germans were unaware of Botha's approach until a forward outpost was surprised by a UDF advance element on 19 March. The Germans, however, managed to hold the UDF at two locations and conducted an orderly withdrawal during the main engagement on 20 March. A third position at Pforte was encircled and overwhelmed; approximately 200 Germans surrendered there. Compounding the loss, a German artillery battery commander abandoned documents at Modderfontein during the disengagement that indicated the Schutztruppe was withdrawing from the southern half of the colony and indicated the intent to retire to the north. This allowed General Botha to concentrate his forces to pursue and eventually conduct an encirclement that would force the German surrender. ${ }^{49}$

As they moved forward, the South Africans also aggressively sought out informants among the local population who provided reports on the strength of the German forces, as well as defensive measures such as land mine and booby-trap emplacements. ${ }^{50}$ The Germans, given their negative history with the indigenous peoples of GSWA, had no counter to the South African tactics.

With the arrival of the new South African Aviation Corps' six Henri Farman F-27 and two BE2C aircraft in the spring of 1915, Botha was able to exploit aerial reconnaissance to locate the Germans and coordinate operations between his own columns. ${ }^{51}$ While the Germans were the first to employ aircraft in the theatre, the German commander, Colonel Victor Franke, sometimes failed to heed the intelligence they provided. A case in point was his choice to disregard information his aerial scouts provided concerning the South African numbers at Trekkopje. His decision to attack an entrenched, superior force, coupled with a failure to surprise the enemy and the presence of a Royal Navy Armoured Car Squadron, ensured the failure of the attack. ${ }^{52}$

\section{Conclusion}

In the final analysis and although the Germans were greatly outnumbered, their failure to use intelligence assets properly - such as reconnaissance forces - or to correct wireless procedures they knew to be poor much hastened their defeat. Only at the Battle of Sandfontein on 26 September 1914, did the Germans successfully use intelligence, terrain and deception to defeat an unprepared, overreaching opponent. ${ }^{53}$ Thereafter, the Germans fought a seemingly reluctant campaign that was marked by hesitation and missed opportunities. ${ }^{54}$

Despite having a better understanding of the terrain and interior lines, the Germans never had a full intelligence picture of their enemy. The Schutztruppe had no dedicated intelligence or reconnaissance units, 
and the assets it did have - airplanes and ad hoc scout elements - did not contribute greatly to the campaign. ${ }^{55}$ Many of the mistakes the Germans made - defensive positions surprised by the sudden appearance of UDF troops to their front (Pforte, Gibeon and Ghaub) and ill-advised attacks on positions with superior numbers and armaments (Trekkopje) - would have been mitigated by proper deployment of reconnaissance forces or thoughtful consideration of the reports that were delivered.

The South African forces under the command of Louis Botha, on the other hand, overcame the initial problems of a hastily organised campaign through brute strength, speed and a good deal of improvisation. ${ }^{56}$ Logistical and engineer elements would be called upon to feed and move a large army through inhospitable desert terrain by rebuilding railways and supplying vast amounts of food and water to over 20000 troops in the northern theatre alone. Botha's forces, assisted to a small degree by Britain's pre-war strategic intelligence collection, were able to defeat the Germans with the help of good tactical and signals intelligence methods. It was a modest contribution, but one that led to a more robust capability for the UDF's difficult campaign in East Africa (1916-1918) and in World War II.

1 The Kaiser insisted to Queen Victoria that "Never was the Telegram intended as a step against England or your Government". Nevertheless, despite Wilhelm's desire for good relations with England, many Englishmen still distrusted Germany's intentions in Africa. See also R Sontag. "The Cowes interview and the Kruger telegram". Political Science Quarterly 40/2. June 1925. 217-247.

2 J Keegan. Knowledge of the enemy from Napoleon to Al-Qaeda: Intelligence in War. London: Hutchinson, 2003, 113-164. Keegan deals only with the role of wireless intelligence in the Royal Navy's pursuit and defeat of the German Kriegsmarine East Asia Squadron and auxiliary cruisers. Other examples include M Seligmann. Spies in uniform: British military \& naval intelligence on the eve of the First World War. Oxford: Oxford University Press, 2006; P Mohs. Military intelligence and the Arab revolt. Abingdon: Routledge, 2008; and a special edition of the Journal of Intelligence Studies 5/2. 2005, which focused on German military intelligence in the Great War.

3 E Paice. World War I: The African Front - An imperial war on the African continent. New York, NY:

Pegasus, 2008, 1.

4 In Europe, however, the South African forces would rely on the British to supply its intelligence.

5 M Seligmann. The Royal Navy and the German threat 1901-1914: Admiralty plans to protect British trade in a war against Germany. Oxford: Oxford University Press, 2012, 10-12.

6 Paice op. cit., p. 3.

7 With the exception of German East Africa's Colonel Paul von Lettow-Vorbeck, who decided to take on the Allies in order to force them to divert resources from the European theatre.

8 PE von Lettow-Vorbeck. Heia Safari! Deutschlands kampf in Ostafrika. Leipzig: KF Koehler, 1920, 4. LettowVorbeck was Germany's most successful colonial commander, surrendering his force in East Africa only after the armistice in Europe.

9 H Strachan. The First World War in Africa. Oxford: Oxford University Press, 2004, 64.

10 Ibid, p. 65.

11 ST Grimes. Strategy and war planning in the British Navy, 1887-1918. Martlesham: Boydell Press, 2012, 71; Seligmann, The Royal Navy ... op. cit., pp. 10-12.

12 Ian van der Waag discusses the South African Army's difficulties in the run up to the war and military operations in "The Battle of Sandfontein, 26 September 1914: South African military, reform and the German South-West Africa Campaign, 1914-1915”. First World War Studies DOI: 10.1080/19475020.2013.828633. For an excellent discussion of the causes of World War I, see C Clarke. The sleepwalkers: How Europe went to war in 1914. New York, NY: Harper, Collins, 2012.

13 A Clayton. Forearmed: A history of the Intelligence Corps. Oxford: Brassey's, 1993, 10; TG Fergusson. British Military Intelligence 1870-1914. London, Arms \& Armour Press, 1984 15, 30-31. 
14 HJG Kamffer. "Om een scherpe oog in't zeil te houden: Die geheime diens in die Zuid-Afrikaansche Republiek". Unpublished PhD thesis, North-West University, Mafikeng, 1999. <http://hdl.handle.net/10394/3141> Accessed on 5 Jan 2012.

15 JJ Collyer. The campaign in German South West Africa: 1914-1915, reprint. Nashville, TN: Battery Press, 1997, 159.

16 J Gooch. The Boer War: Direction, experience and image. New York, NY: Routledge, 2013, 90.

17 It was, and still is today, a very productive way to gain information, accounting for nearly $90 \%$ of overall collection. See comments by Admiral William Studeman at the First International Symposium on Open Source Solutions in December 1992. <> Accessed on 11 Feb 2012.

18 Military attachés as diplomats, however, are generally forbidden from conducting clandestine intelligence collection in accordance with international agreements.

19 Cleverly's reporting covered a wide range of topics; those on Native Affairs in the German protectorate are very negative of the German administration. Cleverly had his detractors in London who felt his reporting was overwrought and unreliable. Many are contained in The National Archives files (TNA) at Kew, especially PRO 244.

20 The German Foreign Office in Berlin thought, or perhaps hoped, its territories would be immune to the coming war. In early August 1914, a message went out to the colonies that they were not in danger. Subsequent events would prove them wrong. H von Oelhafen. Der Feldzug in Südwest 1914-1915. Berlin: Safari Verlag, 1923, 10; T Seitz. Südafrika im Weltkrieg. Berlin: D. Reimer, 1920, 26.

21 Geheimakten: Kommandeur - ST Mobilmachungvorarbeiten [Secret files: Commander - Preparations for mobilisation of the Protection Force], Namibian National Archives, File ZBU 2372, IX.h.

22 Ibid.

23 NO Oermann. Mission, church and state relations in South West Africa under German rule 1884-

1915. Stuttgart: Franz Steiner Verlag, 1999, 103. The missionaries could also be misused by authorities and their information was not always correct; the indigenous peoples could be deceptive as well.

24 Ibid.

25 Geheimakten op. cit. Existing Schutztruppe mobilisation documents from 1913 and before show the Germans expected the South African army to make a cross-border attack across the Orange River. Landings at the port cities of Lüderitz and Swakopmund were not discussed at this point, although a naval blockade was expected. By August 1914, Heydebreck did postulate that landings on the coast might occur.

26 "Historicus Africanus," Der 1. Weltkrieg in Deutsch-Südwestafrika 1914/15, 1. Band, Windhoek: Glanz und Gloria Verlag, 2011, 23.

27 N Parsons. "Colonial administration: Intelligence reporting in colonial Botswana, 1895-1965". University of Botswana. <> Accessed on 10 Feb 2012.

28 See especially the correspondence between the regional magistrates of Bechuanaland and the High Commissioner of the Cape Colony, Botswana National Archives (BNA) RC 11/1 \& RC 11/2 (Hereros). Similarly, Botha refused the proffered assistance of the Rehoboth Basters in GSWA before they rose against the Germans in April 1915.

29 M Seligmann. "A view from Berlin: Colonel Frederick Trench and the development of British perceptions of German aggressive intent, 1906-1910”. pp. 114-147. Journal of Strategic Studies, Vol 23, 2000, Issue 2.

30 FJA Trench, Appendix to Trench's report no. 1, 26 June 1905, BNA, File RC 11/1.

31 The high-powered Telefunken radio transmitter and huge antennae at Windhoek and the smaller stations at Lüderitzbucht and Swakopmund had not yet been built during Trench's time in GSWA. The condensers would be crucial to supply invading troops and horses with adequate water during the campaign.

32 FJA Trench, Letter to the Secretary to the War Office on the possible future use of German Protectorate Troops in SW Africa against the Cape Colony, 15 March 1906, TNA (Kew) File WO 106/269, XXXI.

33 F Trench. "War Office papers: Despatches of Col FJA Trench". TNA (Kew) Files WO 106, WO

181, WO 33. Some Foreign Office and War Office officials in London were, however, concerned that Trench was overzealous in his depiction of German aggressive intent.

34 T Dedering. "The Ferreira raid of 1906: Boers, Britons and Germans in southern Africa in the aftermath of the South African War”. Journal of Southern African Studies 26/1. March 2000. 47.

35 AP Scotland. The London cage. London: Evans Brothers, 1957. Scotland was made a member of the Order of the British Empire for his services, primarily in Europe, during World War I. Although his memoires are autobiographical, there has been nothing to contradict his statements.

36 G Tylden. "South African Intelligence Corps history and insignia". <http://justdone.co.za/saffer/index.php?title=sa_army_intelligence_corps_history> Accessed on 10 Mar 2012. 
37 Baden-Powell, who created the Boy Scout movement in 1909, tried to inculcate the methodologies of scouts and reconnaissance duties into the British Army's cavalry training, but he was rebuffed by more senior general officers such as Douglas Haig and Sir John French, who felt that mounted horse troops were best suited for direct assaults with pennants and lances. The results in the European theatre of war bear witness to the fallacy of their beliefs.

WS Rayner, WW O'Shaughnessy \& L Winethal. How Botha and Smuts conquered German South West:

A full record of the campaign from official information by Reuter's special war correspondents who accompanied the forces sent by the government of the Union of South Africa. London: Simpkin, Marshall, Hamilton, Kent, 1916, 36.

39 Collyer op. cit., p. 163.

40 RR Hennig. Deutsch-Südwest im Weltkrieg. Wolfenbüttel: Melchior Verlag, 2011, 121.

41 A Jacobs \& H Smit. "Topographic mapping support in the South African military during the 20th century". Scientia Militaria 32/1. 2004.

42 Union Defence Force (UDF), South Africa in the Great War 1914-1918: Official history, originally published 1924, reprint. Nashville, TN: The Battery Press, 2004, 50.

43 Collyer op. cit., pp. 162-164. According to Collyer, the UDF's Topographic Section was one of the few intelligence elements capable of providing support to the field forces, and then only to the Northern Force and with limited capabilities; it had four men and one wagon during the campaign.

44 Von Oelhafen op. cit. p. 209; V Franke. Tagesbuch: 1896-1920. Personal Diary (unpublished), 981.

45 Van der Waag op. cit.

46 Union Defence Force (UDF), South Africa in the Great War 1914-1918: Official history, originally published 1924, reprint. Nashville, TN: The Battery Press, 2004, 58.

47 JGW Leipoldt. "Report on operations in German South West Africa submitted to the War Office by the South African government". <> Accessed on 12 Mar 2012. Leipoldt was appointed as Captain in the South African Permanent Force, one of the first 51 officers commissioned in July 1912. He would be instrumental in forming the Intelligence sub-branch in the UDF headquarters in late 1917. See IJ van der Waag. "Major JGW Leipoldt, DSO: A portrait of a South African surveyor and intelligence officer, 1912-1923". Scientia Militaria 25/1. 1995. 1234.

48 Von Oelhafen op. cit., p. 179.

49 G L'Ange. Urgent imperial service, South African forces in German South West Africa, 1914-1915. Rivonia: Ashanti, 1991, 189.

50 Collyer op. cit. The UDF experience with local guides was spotty. On at least two occasions, commanders had to relieve their guides and navigate by compass and dead reckoning because their advance had gone astray.

51 JOEO Mahncke. "Aircraft operations in the German colonies: 1911-1916, The Fliegertruppe of the Imperial German Army". Military History Journal 12/2. http://samilitaryhistory.org/vol122jm.html, Accessed 22 Feb 2012.

52 Kriegsgeschichtliche Forschungsanstalt des Heeres (KFH), Der Feldzug in Deutsche Südwestafrika, 1914-1915 (Entwurf). Potsdam: KFH, 1943, VI/82. Secondary sources are conflicted as to the German intelligence on the armoured cars. Gerald L'Ange states the pilot misidentified the vehicles as water tankers, while German sources imply the commander was unaware of their existence before the attack began. L'Ange op. cit., p. 238. See also Von Oelhafen op. cit., p. 187.

53 RC Warwick. "Reconsideration of the Battle of Sandfontein: The first phase of the German South West Africa campaign, August to September 1914". Unpublished master's thesis, University of Cape Town, Cape Town, 2003. The Germans were led by LTC Joachim Heydebreck at this battle. He was killed in November 1914 during the demonstration firing of a new rifle grenade and succeeded by LTC Victor Franke.

54 KFH op. cit., IX/151.

55 Ibid., IX/149.

56 Van der Waag, “The Battle of Sandfontein, 26 September 1914: South African military, op. cit., p. 19. 